\title{
End-user engagement: The missing link of sustainability transition
}

\section{for Australian residential buildings}

\begin{abstract}
This paper argues that attempts to transform Australia's urban environment into a sufficiently sustainable one has been misdirected. The 'green rating tool,' industry's adherence to relevant standards and governmental policies represent the primary means of effecting the sustainability transition.

However, only high-profile commercial building owners seem interested in being green-rated; the actual end-users of buildings are far less committed (e.g. employees ensconced in commercial buildings and residential home occupiers). Through a systematic review of 103 journal articles published on the topic of end-users and sustainability transition, original findings are presented. The findings reveal that most residential end-users do not purchase green homes and without their 'buy-in,' sustainability transition across Australia will continue to fail. This paper offers a critical analysis of the status-quo, identifying where the effort to generate a sustainable urban environment has been misdirected, what challenges prevail, and why residential end-users have been overlooked. In looking for a way forward that engages end-users, the paper proposes that financial incentives for the purchase of low-carbon buildings must be introduced into the residential real-estate market. And the modeling for this rebate is discussed in terms of emissions trading schemes or carbon tax.
\end{abstract}

Keywords: Sustainable buildings; Occupants; Green transition; Low carbon living; Livable cities; Sustainable cities 


\section{INTRODUCTION}

Sustainability is a major challenge confronting the $21^{\text {st }}$ century, with climate change and rising energy prices underscoring the need to seriously reconsider prevailing built environment practices (Chileshe et al., 2018; Tam et al., 2018). However, sustainability research in the built environment, has predominantly focused on green rating tools (Martek et al., 2019); two reasons are apparent (Doan et al., 2017; Van der Heijden, 2016). First, criteria are needed which collectively constitute the 'sustainability' that is being sought - creating extensive discourse on what does, and does not constitute sustainability, and what factors should, and should not be included in rating tools (Shad et al., 2017). Second, how best to measure each criterion presents an emergent problem (Mattoni et al., 2018). Quantitative parameters (e.g. energy usage) lend themselves to scientific (independently replicable) results but the means of measuring qualitative parameters (e.g. equity or well-being) are more contentious (Li et al., 2018; $\underline{\text { Luther, }}$ 2017). These two reasons have generated a plethora of rating tool configurations, resulting in a third complication - which configuration should we trust and use?

Against this backdrop, a comprehensive review of extant literature reveals a conspicuous neglect of the singular most important stakeholder to the whole sustainability project, namely the end-user (WarrenMyers, 2017; Zhang and El-Gohary, 2016). Evidence suggests that residential home owners (as the largest demographic of end-users) vis-a-vis commercial occupants and their employees have largely been overlooked (Tapsuwan et al., 2018; Warren-Myers et al., 2018). In overlooking the concerns of residential end-users, significant opportunities for realizing Australia's commitment to zero carbon emissions have been lost (ASBEC, 2016; ClimateWorks, 2018; Rameezdeen et al., 2019; van der Heijden, 2014, 2015). Indeed, overall energy intensity in Australia has only slightly improved; around 5\% in the residential sector (ASBEC, 2017). Although some research on end-users' perspectives has been conducted, endusers' views have been represented as passive to the process; neglecting to build or buy sustainable houses only because they are unavailable to them (Martek and Hosseini, 2018; Martek et al., 2019; Warren-Myers et al., 2018). 
This study aims at addressing these things; this is an effort to understand the role of end-users in generating more sustainable residential buildings, as well as what is actually being done, and can be done, to effect transition within Australia to a more sustainable built environment. The premise is argued from a digest of the literature, since the evidence substantiating the claim made here arises from the observation that most literature on sustainability transition in Australia fails to consider the residential end-user; their role, interests or impact (Martek et al., 2019; Tapsuwan et al., 2018; Warren-Myers et al., 2018).

\section{RESEARCH APPROACH AND METHODS}

An inductive methodological approach is selected with the literature constituting the unit of analysis. The epistemological foundation for this research is based upon an interpretivist approach applied to that existing body of knowledge. Following Lin (1998), the interpretivist work combines data acquired from the literature into systems of belief whose manifestations reveal causal mechanisms specific to a case. The Scopus database is selected because of its wide range of coverage, faster indexing process and the availability of more recent publications (Hosseini et al., 2018). A wide range of interchangeable terms is utilized for referring to the concept of sustainable buildings and by different authors (Olubunmi et al., 2016), consequently searching within Scopus comprised several possible combinations of this concept: green building, sustainable building, sustainable construction, sustainable house, green construction, sustainable office, and sustainable property, following . Given the study's focus on end-users, the terms: owner, user and occupant were used to limit studies to those having these terms mentioned in the abstract, title or keywords. This identified 2,442 studies published in a wide range of areas. To concentrate on areas of interest, subject areas unrelated to the topic under investigation were excluded, resulting in inclusion of studies only in several related fields with 1,923 published studies: Engineering; Environmental Science; Social Sciences; Energy; Business, Management and Accounting; Economics, Econometrics and Finance.

The studies were further granulated for Australia to contextualize the research scope and only journal articles were retained as these represent the most influential research available (Darko and Chan, 2016a; 
Hosseini et al., 2018). The final dataset comprised 103 journal articles (interested readers should refer to the Appendix to view the Scopus code utilized).

\section{AUSTRALIA'S SUSTAINABILITY SCORECARD}

Buildings are major sources of damage, and consume one-third of all the Earth's resources (Doan et al., 2017), including one-sixth of all freshwater, one-quarter of all trees and $40 \%$ of all other materials humans make and use (Dixit et al., 2013). 10\% of world energy is embodied within building materials, with a massive $50 \%$ being consumed by building operations and maintenance (Chileshe et al., 2018). Indeed, $80 \%$ of all green-house gases are attributable directly to urban residents and their associated affluence (Hoornweg et al., 2011) and almost half the world's waste is generated in building construction and demolition (Udawatta et al., 2015). Australia's construction, maintenance and use of buildings constitutes around 25 per cent of its annual carbon emissions - measuring four metric tonnes annually (van der Heijden, 2018).

In response, Australia subscribes to the Paris Climate Accords, promising to wind back carbon emissions to just $28 \%$ of 2005 levels by 2030, landing on net zero emissions by 2050 (ClimateWorks, 2016). This is no small feat, given that Australia lacks a comprehensive national strategy to meet its declaration to become a carbon neutral economy and it has the highest population growth rate in the developed world (ABS, 2018). Residential builds are expected to rise from 6 million in 1990 to over 10 million by 2020 (Saman, 2013). Sydney alone is forecast to build 664,000 new houses by 2037 (Foong et al., 2017), while Melbourne is expected to grow even faster, adding 720,000 houses by 2031 (Martek and Hosseini, 2018). Consequently, Australian targets are effectively the most ambitious world-wide, exceeding those set by the European Union, Japan, Canada, South Korea, China or the US, pre Trump (Australian Government, $\underline{2018}$.

In the absence of a federal strategy, progress is being spearheaded by Australia's municipal councils via

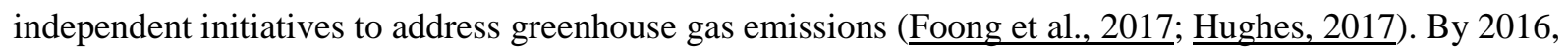
over $80 \%$ of Australian local governments had set zero emissions targets for their operations (Beyond 
Zero Emissions, 2018). All major cities have 100\% renewable energy targets, with above minimum green standards set for public buildings (Hughes, 2017). However, cities have limited resources at their disposal and even less legislative power needed to realize their sustainability aspirations. Moreover, while councils represent the vanguard of Australia's efforts, only $18 \%$ of the communities they serve have been set comparable targets, with fewer still embracing them (Beyond Zero Emissions, 2018; $\underline{\text { Harrington, 2017). }}$ For example, Melbourne has set a target of zero net emissions by 2020, with a $50 \%$ reduction in energy usage for both commercial and residential buildings. To support this goal, Melbourne city enacted a raft of proactive measures including: incentives for developers to exceed minimum mandatory green ratings; the 'City Switch' scheme to help businesses reduce energy consumption and waste generation; the '1200 Buildings' program to foster sustainable retrofitting; and the 'Environmental Upgrade Scheme' that offers cheap financing to encourage building owners to go green (City of Melbourne, 2018). Melbourne will not come close to reaching its targets; as early as 2014, the City's update noted:

"If the municipality of Melbourne continues on its current trajectory, forecasts reveal annual greenhouse gas emissions will grow to around 7.7 million tonnes by 2020 - a $60 \%$ increase on 2010 emissions."

(Harrington, 2017)

Australia's other major cities (e.g. Sydney and Adelaide) exhibit a similar trend given that such a target requires massive transformation of cities, societies, economies and politics (Candy et al., 2017).

Failure, however, is not an inevitability. There are some significant success stories around the world, and these carry lessons for Australia. Success is promoting the near zero carbon house agenda, as well as, the successful lobbying of stakeholders in influencing the adoption of energy saving homes, in Italy (Albino and Berardi, 2012), Denmark (Alberg Mosgaard et al., 2016), Singapore (Siva et al., 2017), and across Europe (Ruggiero et al., 2014) can provide examples for Australia. All these comparisons point to the importance of home owners' power, interest and awareness as critical factors in sustainability transition (Berardi, 2013). The construction sector is a multi-agent, integrated dynamic process which cannot be simplified, and therefore, if residential end-users do not purchase green homes, namely, without their 
'buy-in,' sustainability transition across Australia will continue to fail (Martek et al., 2019), as discussed next.

\section{AUSTRALIA'S GREENING STRATEGY}

Australia has a strategy of legislating minimal mandatory codes and standards, combined with expectations of higher levels of compliance through voluntary uptake (Berry and Marker, 2015; $\underline{\text { Mcguirk }}$ et al., 2015; Smoleniec et al., 2017) (refer to Figure 1). Energy efficiency targets were subsequently introduced into regulations in 2005 for residential dwellings and 2006 for commercial buildings, following UK precedents (Wilkinson, 2014). In 2008, the Green Building Fund was established as an initiative to mitigate the perceived risk of climate change. Its aim was to forge closer collaboration between government, business and industry in an effort to reduce energy consumption and greenhouse

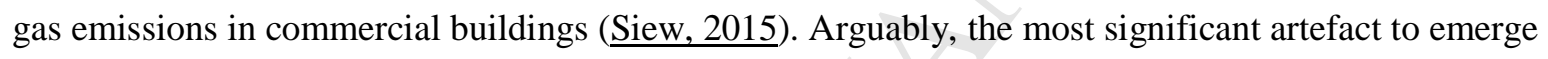
out of the ensuing discourse was the 'green rating instruments.' Their emergence began in the UK, in 1990, with the Building Research Establishment Environmental Assessment Method (BREEAM).

BREEAM considers a building's whole lifecycle (design, construction, operation and refurbishment) and measures environmental performance across eight criteria (i.e., land use, transportation, materials, energy, water, waste, pollution and management). BREEAM operates in some 75 countries and accounts for $80 \%$ of green certifications issued in Europe - some 560,000 buildings (BREEAM, 2018; Doan et al., 2017). Similarly, Leadership in Energy and Environmental Design (LEED) was developed in the US, dominating the market there and operating across 160 other countries. It measures six performance criteria, namely: site, materials, energy, water, resources and internal environment (LEED, 2018). The Comprehensive Assessment System for Built Environment Efficiency (CASBEE) is a Japanese rating tool variant. CASBEE differs from the other tools because rather than impute credits for positive actions taken across measured criteria, it assesses the cumulative impact of positive improvements of a building's internal environment against any consequential negative repercussions on the building's contextual surroundings (CASBEE, 2018). 
The Green Building Council of Australia (GBCA) launched Green Star, in 2003 (van der Heijden, 2018) as a voluntary design rating tool that relies upon existing regulations (Xia et al., 2013). To its credit, Green Star has deliberately sought to be adaptive, seeking to assess a range factors (management, environment quality, energy, transport, water, materials, land use, emissions and innovation) as well as tailoring its instrument according to building usage (i.e., office, educational, health and multi-unit residential) (Iyer-Raniga et al., 2014). In 2013, it had close to 400 projects but as of March 2018, it had over 1,700 thus, demonstrating increasing interest in the scheme (GBCA, 2018). NABERS, a performance rating tool, was launched in 1998 in NSW, and in 2005 it became a nationwide voluntary instrument to measure resource consumption of existing buildings (Iyer-Raniga et al., 2014). As a consequence of the Building Energy Efficiency Disclosure Act, 2010, a NABERS energy certificate is needed for office buildings beyond a certain size but no specified level of certification is mandatory. NABERS has a relatively high participation rate, close to 77 per cent, in energy labelling of office buildings (van der Heijden, 2018).

\section{$<<$ Insert Figure 1 Here $>>$}

Figure 1. Major sustainability/green rating systems, with parallel trends in Australia (source: authors)

Green Star and NABERS are Australia's most widely used tools (Mao et al., 2009) because they provide a better fit to Australian conditions vis-à-vis BREEAM (Bondareva, 2008). Even so, BASIX, EMGB, NABERS, AccuRate and NatHERS represent further rating tool permutations tailored to Australia (Iyer-

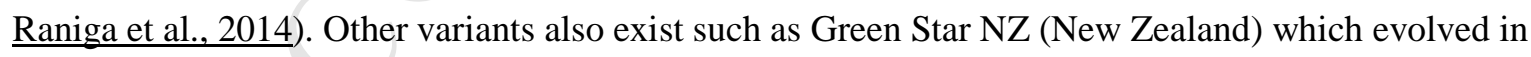
2007 out of the 2003 Australian parent (Doan et al., 2017; Mao et al., 2009). Elsewhere, BEPAC includes 30 criteria in its complement of measures, while GBTool has 120 (Ding, 2008).

The upsurge of the green rating tool and proliferation of over 600 rating tool sub-species has its own consequences (Vierra, 2016). From one perspective, the hunt for a transition to sustainable buildings has metamorphized into even more elaborate and sophisticated sustainability assessment systems that 
transcend the rating tool itself; a discussion of which is beyond the scope of this paper, but includes: value chain assessment (ㅂall, 2014), whole of life-cycle, intelligent buildings (Ghaffarianhosseini et al., 2016), optimized modeling, resource efficiency (Ness and Xing, 2017), cooperative incentivization (Wu et al.,

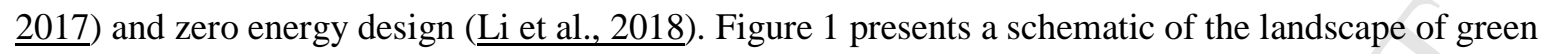
rating tools in Australia.

\section{THE LIMITS OF SUSTAINABILITY RATING TOOLS}

Due to the limitation of mandatory requirements like building codes (c.f.Van der Heijden, 2016), rating tools remain prime-movers in the push to curb environmental greenhouse gas emissions, improve energy efficiency, and deliver broader sustainability objectives such as social justice (Martek et al., 2018; $\underline{\text { Van }}$ der Heijden, 2016). Rating tools are the most recognizable mechanism by which to appraise a building's 'greenness' (van der Heijden, 2015). Some tools calculate a quantified metric for the criteria they measure; others, like Australia's Green Star, ascribe a 'star rating;' with a six stars building being considered the most environmentally friendly (Ding, 2008; Doan et al., 2017). These scoring systems provide a language for ranking and comparing buildings. By tapping into the competitive urge of corporations to 'virtue signal' and out star each other, rating tools aim at influencing the rest of the market to incorporate green into standard practice (Bondareva, 2008; van der Heijden, 2014). Several drawbacks with sustainability rating tools though were aptly described by Marjaba and Chidiac (2016): "These certification systems have yet to produce metrics that are repeatable, reproducible and a true reflection of building performance."

Rather than establishing a definitive benchmark for comparing one building to another, rating tools have

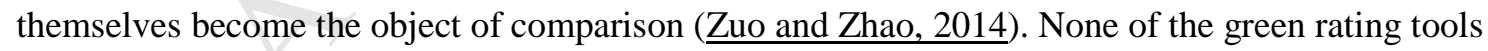
developed are wholly mandated by government and seek market-place acceptance (Doan et al., 2017; Vierra, 2016), that is, vying for endorsement and patronage from the very entities they propose to regulate. Herein lies a critical weakness of the rating system - it is voluntary and unregulated. 
Currently, tools remain a work-in-progress, with providers continually updating their product in response to market development and criticism; whilst in ipso such is necessary, it does signal to users that the validity of rating tools remains an unresolved and contested matter (van der Heijden, 2018). A study by

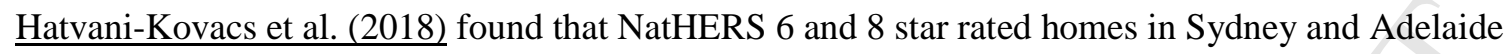
actually underperformed traditional non-star rated homes and fueled public condemnation on the credibility of rating systems (Sutton, 2018). Indeed, recent academic work on rating tools has been overall more negative than positive (Martek and Hosseini, 2018; Van der Heijden, 2016).

The integrity of the claims has therefore, has been questioned (Martek and Hosseini, 2018; Zuo and Zhao, 2014). The criteria measured also carries subjectivity, i.e., ratings accrue according to the total score a building reaches across the measured categories (Doan et al., 2017). It is not merely that the criteria for each tool are different, or that they are differently weighted, but that collecting points is easier under some categories than others (Xia et al., 2013; Zuo et al., 2018). For example, just having a Green Star accredited professional on the building management team wins points. Consequently, it comes as no surprise that this criterion is the most commonly awarded, with $94 \%$ of Green Star rated buildings claiming this achievement (Doan et al., 2017). Furthermore, the cosmetic gesture of just installing bicycle parking racks outside a building wins points. However, points for innovation are the criterion least often claimed, at $35 \%$ of rated building; notwithstanding the fact that innovation is the backbone of progress (Xia et al., 2013). Zuo et al. (2018) identified that of 264 Green Star rated buildings studied, only 16\% were awarded the top tier of six stars (and innovation was essential to achieving that rating). The categories of energy and emissions figured in five-star rated buildings, while in achieving four stars, buildings scored their points predominantly across the categories of management, transport, water and materials (Zuo et al., 2018; Zuo and Zhao, 2014). For lower star accredited green buildings, the impression is that they may not actually be contributing significantly to improving urban sustainability at all. At worst, they may be manifestations of 'greenwashing' - the pretense of appearing to be environmentally compliant (Martek and Hosseini, 2018). 
Matters are further complicated by the fact that each rating tool carries its own unique list of items and the measurement of these are inconsistent. Most rely on measurements sourced from building documentation not measurements obtained from the building's actual performance (Luther, 2017). For example, an urban master-plan, assessed at the design stage, would be 'predictive.' Assessment of the operational performance of a building, say 12 months after commissioning, would be 'measured.' In contrast, tools such as LEED ND operate by providing 'prescriptive' processes to be followed. Real-time performancebased measures are the most reliable and in that regard, preferred. But they are initiated after the fact, have less bearing on sustainability consequential decisions, and require significant resources and trained personnel to undertake the measurement. While more accurate, they are more expensive and less helpful in shaping sustainability outcomes ( $\mathrm{He}$ et al., 2018). Some tools advise on what actions are needed to achieve sustainable outcomes, while others measure whether those outcomes are achieved but no tool does both (RC, 2018).

Indeed, the environmental impact of buildings, as assessed by sustainability rating tools remains uncertain (Martek et al., 2018; Papajohn et al., 2017). Tam and Zeng (2013) argue that the plethora of rating instruments, with their varied range of criteria, represents an admission that a building's impact upon the planet is largely unknown, concluding "there is no consistent environmental information available in today's marketplace." If buildings are to be sustainable, a whole life-cycle perspective of materials is needed (e.g. manufacture through to demolition and recycling) (Chileshe et al., 2018). Implicated here is the possibility that actions undertaken to improve sustainability outcomes at one point in the value chain come at the cost of adversely impacting other points in the chain (Hosseini et al., 2017). For example, while a better thermal envelope may yield operational energy-saving benefits to a building, this comes at the cost of additional embodied energy in the wall material, insulation and double glazing (Crawford et al., 2015). Similarly, Mulvaney (2013) contends that while solar panels offer free energy, they are heavy in embodied energy, and are replete with rare-earth elements that pose a considerable environmental hazard at time of disposal. 


\section{ENHANCING SUSTAINABILITY TRANSITION: CRITICAL SUCCESS FACTORS}

An effective rating tool requires more than just a list of sustainability criteria and a means of measuring them (Love et al., 2012) - and this is where government can assist (Love et al., 2012; Olubunmi et al., 2016). Distilling the recommendations of Berardi (2015), Sulivan et al. (2014), Gil and Durante (2011),

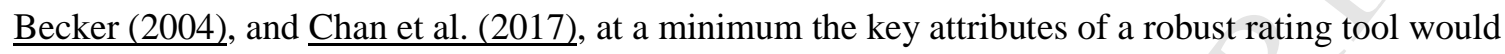
entail:

- Holistic vision of the built environment;

- National and local synergies with international objectives;

- Clear articulation of what constitutes sustainability and environmental themes;

- Transparent metrics, measurement methods and evaluative criteria;

- A framework for integrating value chain inputs into targeted outcomes;

- Effective transitioning of existing industry standards to new paradigms;

- Capacity to refine goals, processes and technologies in response to developments; and

- Critically, strong ability to communicate with stakeholders and achieve community buy-in Moreover, the impediments to effective uptake of a sustainability culture within the Australian construction industry have also been examined and reveal that these involve more than just tweaking the rating tools (Love et al., 2012; Mcguirk et al., 2015; van der Heijden, 2015). The comprehensive work by Harrington (2017), in tracking the sliding failure of Australia's national sustainability agenda to gain marketplace traction, proposes through its Best Practice Policy Framework, a set of remedial solutions. Recommendations are three pronged, targeting market regulation, financial incentives and what it

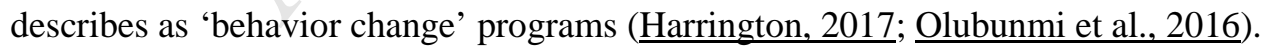

Financial incentives should offer both 'carrot and stick': grants for building sustainability renovations, loan concessions for adopting innovations and tax breaks for producer subsidies, along with 'feebates.' (Mcguirk et al., 2015) Disincentives for resisting sustainable practices would come in the form of carbon 


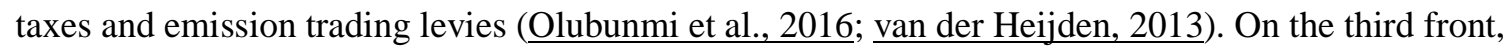
Harrington (2017) recommendations for community engagement are far more vague; voluntary standards, commitment programs and engagement information tools.

Indeed, a comprehensive review of articles published on the sustainability challenges facing the built environment reveal two striking points. First, only a few broach the topic of end-user engagement but second, a number of articles make clear that lack of stakeholder participation remains the single greatest impediment to gaining better sustainability outcomes - without community buy-in, sustainability remains a fringe movement (ASBEC, 2017; Becker, 2004; Hakkinen and Belloni, 2011; Sulivan et al., 2014; van der Heijden, 2015; Zuo and Zhao, 2014).

\section{END-USERS AND SUSTAINABILITY TRANSITION}

The current state of sustainability transition in Australia, points towards the pivotal role of end-users. First, $\underline{\text { Hoffman and Hen (2008) }}$ proffer that sustainability in the built environment is "predicated on encompassing strategies, techniques, and construction products that are less resource-intensive or pollution producing than regular construction." Thus second, if meaningful 'greening' of the urban environment is to occur, it must be undertaken with a 'whole-of-life-cycle' approach (Chileshe et al.., 2018; Tam and Zeng, 2013), adopting newer, leaner, innovative methods such as prefabrication (Arashpour et al., 2018; Doan et al., 2017), and must occur at an industry level in order to foster needed knowledge acquisition while overcoming entrenched logistical and regulatory barriers (Marjaba and Chidiac, 2016).

But most importantly, the people involved who are not earning a living from the green agenda, or policy wonks lobbying their cause, must be convinced (Armitage et al., 2011; Centre for Liveability Real Estate, 2018; Martek et al., 2018; van der Heijden, 2018). The earlier builders and owners are involved in a project, the better the sustainability outcomes (Armitage et al., 2011). But the reasons for not going green are compelling: 1) higher costs for green building materials; 2) complicated approvals processes; 3) greater risks in utilizing uncertain green technologies and processes; 4) uncharted legal and contractual 
issues; 5) lack of relevant expertise amongst sub-contractors; 6) lengthier time periods to completion; and 7) insufficient return on green investment (Darko and Chan, 2016b; Productivity Commission, 2013;

Sandy, 2011; Tam and Zeng, 2013; Wilson and Tagaza, 2006). In total, 25 detractors preventing building owners from adopting green construction have been identified (Gan et al., 2015). In a study by $\underline{\text { Shen et al. }}$ $\underline{(2010)}$, of 87 projects which measured the 'triple bottom line' outcomes of economy, environment and equity across 35 sub-categories, economic priorities were found to far outweigh the other two. Indeed, even where developers are aware that energy costs can be reduced by $26 \%$ in adopting a green building solution, the perceived risks and higher upfront costs prove enough of a disincentive for them to choose a conventional 'non-green' building solution ( $\underline{\text { Shi et al., 2016). }}$

\subsection{End-user perceptions of green buildings}

More alienated from the green-building agenda than government, developers and builders, are the building occupiers themselves (ASBEC, 2017). That said, evidence shows that buildings designed with users in mind achieve better sustainability outcomes, than when designing to win high star ratings (Armitage et al., 2011; Centre for Liveability Real Estate, 2018). The psychological, healing and social benefits are similarly well documented: shorter stays in hospitals, improved health, less on-the-job stress, greater productivity (Wells, 2000), self-discipline (Taylor et al., 2002), improved powers of concentration (Ottosson and Grahn, 2005) and overall improved mood and happiness (Hartig et al., 2007). Moreover, green features improve the capital value of properties: having trees adds up to US\$1.1 million to property prices in the US (Thomas, 2010), and as much as 30\% increase of property prices in Australia (Gonzalez, 2007). In a case-study of a retirement village, Zuo et al. (2014) showed numerous benefits associated with a greener building such as safety and security, peaceful surroundings, a site layout conducive to positive community interactions and enhanced independence and quality of life.

These observations are in contrast with results achieved when specifically designing buildings for green ratings. For example, Ravindu et al. (2015) conducted a occupancy evaluation of a LEED platinum certified factory and revealed that thermal comfort, ventilation, and ability to control environment, were 
all less satisfactory than in comparable conventional facilities. Similarly, Paul and Taylor (2008), conducted a post-occupancy evaluation of a RAIA award winning campus building in Australia and reported that users perceived limited benefit in terms of comfort, ventilation, humidity, acoustics or even aesthetics. Several studies on targeted phenomenon, such as glare and heat stress, reveal that green rated buildings are poorly appraised by users ( studies that consider a basket of criteria also reveal that green rated buildings were poorly evaluated occupants (Gou et al., 2013), or at best, reveal conflicting perceptions among stakeholders (삼mitage et al., 2011; Shi et al., 2016).

The findings from Australia concur with research conducted in other countries. In a study conducted in Toronto, Canada (involving 165 occupants of four LEED Gold certified buildings), occupants felt that the buildings did not perform as promised by the rating (Gorgolewski, 2014). A similar study conducted in Shenzhen, China (involving 182 occupants) of a showcase green building development revealed similar disappointment ( $\underline{\mathrm{Lau}, 2013})$. A Swedish study (involving 2,113 occupants of sixteen office buildings) found that people were neither more satisfied nor more productive in green commercial buildings (Freig et al., 2013), while another Swedish study of residential housing that collected the perceptions of 477 people, also confirmed that there was no statistical difference in the satisfaction experienced between green and conventional dwellings (Zalejska-Jonsson, 2014). Indeed, studies that did reveal higher satisfaction in green buildings, the effect wore off quickly after people moved in.

\subsection{End-users perceptions versus analysis: The contradiction}

As discussed, the discourse reveals contradictions between research that claims strong benefits and research that is far more ambivalent. First, performance expectations may be misleadingly reported as equivalent to experienced outcomes. There is evidence that suggests occupants' expectations of sustainable building outcomes are not borne out by lived experience. The study by Jailani et al. (2015) on tenant perceptions of green office buildings in Melbourne, found that across all five parameters investigated (design and flexibility, lighting and acoustics, HVAC systems, equipment and maintenance 
and, thermal comfort and air quality) none of the initial performance expectations were realized in the final delivered building. Moreover, the gap between expectation and realized performance was hardly different between 4,5 , or 6 star rated buildings.

Second, and perhaps more importantly, corporate owner occupiers tend to inflate the perceived benefits of their green-accredited buildings far in excess of their own employees' estimations (Armitage et al., 2011;

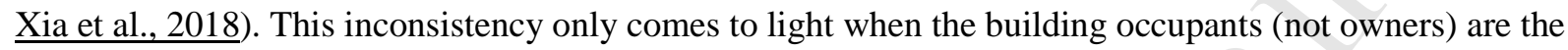
subjects of the investigation. For example, the Property Council of Australia predicts productivity benefits of up to $10 \%$ accrue to green buildings (Property Council of Australia, 2001). Given that salaries (particularly in services industries) can account for as much as $90 \%$ of corporate costs (Armitage et al., 2011), this translates, in a US study, to an estimated US\$55 (2003 dollars) saving per $\mathrm{ft}^{2}$ ( $\underline{\text { Kats, 2003) }}$. However, it is also argued that "there is no clear definition of productivity in the office environment," (Mallawaarachchi et al., 2017) while, actually measuring non-manufacturing productivity has proven to be highly problematic (Leaman and Bordass, 2001).

The open plan office represents the most notorious example of this. The open office has been widely peddled as the most conducive work environment that facilitates teamwork, communication, collegiality and equity outcomes; it improves thermal, lighting and air quality conditions, is highly adaptable and raises productivity. The claim is so universally accepted that it is now an unchallenged office design paradigm - despite extensive anecdotal evidence from workers to the contrary ( $\underline{\text { Sander, 2018)}}$. A recent study by $\underline{\text { Sander (2018) }}$ uniquely examines the issue from the employees' perspective, concluding that employees spent $73 \%$ less time in face-to face interactions, while email use shot up $67 \%$ (c.f.Shafaghat et al. (2015)).

$\underline{\text { Kato et al. (2009) }}$ and Armitage et al. (2011) make the distinction between employer and employee perspectives clear - managers and workers from nine Green Star rated building, located in major cities around Australia, were surveyed. Management reported that their buildings enhanced employee retention, increased productivity and increased competitive advantage. Workers reported differently; noise levels were high, privacy low, fatigue and lethargy commonplace and satisfaction was poor. Only $51 \%$ agreed 
that their office enhanced productivity. Ironically, the greatest advantage reported by employees of occupying a 'green building' was boosted reputation imputed by company visitors (Kato et al., 2009). To quote Gou and Xie (2017): "It is becoming increasingly evident that focusing on getting more points for 'doing less harm' as encouraged by current green building tools, will not necessarily produce design solutions that support and strengthen the human-nature system." End-users, even in the corporate and commercial sector, remain skeptical of green rating tools (DECC NSW, 2014). However, people are increasingly aware of the expectation that government and corporations will make good to clean up the urban environment and make it livable, for this and future generations (Mapes and Wolch, 2011).

\subsection{End-users and green marketing}

Motivational drivers to adopt green buildings are more complex than suggested by the parameters measured by rating tools (Hakkinen and Belloni, 2011; Olubunmi et al., 2016). In other words, green buildings are not pursued because building owners want improved performance across a range of measures; they want the endorsement imputed by green rating tools, along with any accompanying accolades (Sandy, 2011; Wilson and Tagaza, 2006). Olanipekun et al. (2017) noted internal external drivers to 'go green' are internal or external, where external drivers include financial incentives and government regulation. That said, internal drivers are stronger, with 'enhanced reputation' key among them (Olanipekun et al., 2017; Xia et al., 2018). In a study by Li et al. (2013), twenty-four academic building projects for Australian universities were investigated in an effort to understand why they chose to invest in green facilities. Four factors were extracted from 354 considerations: 1) functional needs fulfillment; 2) environmental considerations; 3) finances; and 4) reputation and publicity. Of these, 158 (or $45 \%$ ) related to enhancing reputation; outranking even meeting specific needs. Media releases that accompany these buildings are brazenly self-congratulatory. For example: the Bond University Mirvac buildings is known as the first Australian university building to attain 6 Star 'World Leadership' status from the GBCA (Bond University, 2011). In a study on occupant satisfaction of the Mirvac facilities by Leaman and Bordass (2007), 85 users were interviewed, and an interesting anomaly arose. Both resident 
and transient users acknowledged overall satisfaction with the building, however when questioned on specifics (such as lighting, noise and temperature), respondents registered performance problems.

Leaman and Bordass (2007) posits an interesting explanation for this discrepancy, suggesting that the occupants of green buildings become more tolerant of their buildings' shortcomings. Indeed, the performance 'forgiveness index' for the Mirvac building was assessed as within the $85 \%$ percentile (Best and Purdey, 2012).

Understanding that rating tools are largely a corporate marketing instrument helps explain why private

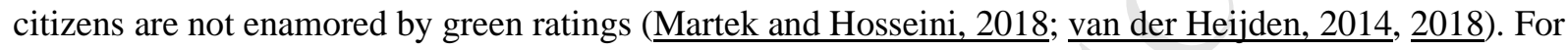
them, genuine cost-benefits of going green remain uncertain and they have no need of 'virtue branding.' The costs of building a sustainable, green compliant building have been reported to be between $10 \%$ and $30 \%$ over the cost of traditional construction methods (Ang and Wilkinson, 2008). This reemphasizes the point that there are additional costs, and that these costs are uncertain (Onuoha et al., 2018). Moreover, the lengthy approvals period and additional risks posed, detract further (Darko and Chan, 2016b) given that the bargaining power of price-driven residential end-users remains poor, it falls to government to offer leadership (Olubunmi et al., 2016). Perhaps the best positive example is the introduction of BASIX (residential sustainability index, which has been mandatory in NSW since 2004), with accompanying incentives schemes for end-users (Ding, 2013). Although a survey revealed that half the respondents found the BASIX tool and its accompanying websites not particularly accessible, from a 'glass-half-full' perspective, half did (Ding, 2010). In time, industry will engage further with better familiarity and industry practice innovations, while end-users are expected to grow more sympathetic (Centre for Liveability Real Estate, 2018).

\subsection{End-users: Analysis of expectations}

Expectations and requirements of ordinary end-users from sustainable buildings are high on the agenda in sustainability transition research (Altmann, 2014; Ambrose, 2015). Oddly, while being the largest building user market segment, scant research in Australia has focused on what ordinary people want from 
their buildings (Tapsuwan et al., 2018). One argument suggests that because Australia has the highest energy costs in the world, a green rated house would be desired because it indicates lower energy usage (Centre for Liveability Real Estate, 2018). That said, home-owners have a greater incentive to invest in green energy-saving modifications, and while landlords do not (given that energy savings would be passed on to their tenants (Gabriel and Watson, 2012)), home-owner households have been shown to expend $13 \%$ more for energy than home renters, even when prices are controlled for income, dwelling type, climate and household size (Gabriel et al., 2010).

Case study research by Tapsuwan et al. (2018) found six expectations of residents of a sustainable neighborhood: 1) economic growth; 2) health of neighborhood; 3) social amenities; 4) community; 5) safety; and 6) connectedness (accessibility). When examining the sub-categories within each factor, most are not considered by major green-rating tools, as argued by Martek and Hosseini (2018). For example, 'low crime rate,' was an extremely high priority - and included within the Brundtland Commission Report on sustainability. Similarly, requirements for 'good roads' and 'good public transport' are the preserve of government and planning, while 'employment opportunities' and 'better retail services' are an economic outcome. Moreover, priorities highlighted by citizens, are not part of any of the myriad sustainability policy strategies that government have produced (van der Heijden, 2018). Regards what the current sustainability project should be delivering to the nation, it appears that government and the public are talking somewhat past one another, as argued by van der Heijden (2018) and Tapsuwan et al. (2018).

\section{ENGAGING END-USERS: THE WAY FORWARD}

Akin to other 'politically correct' issues, sustainability is ubiquitous within extant literature and seldom rejected (Martek et al., 2018). Despite the monumental effort and widespread consensus as to the worth of this objective, the Australian building industry has made little progress (Saman, 2013; van der Heijden, 2018). Australia will not come close to achieving its Paris Climate Accord agreements (Harrington, 2017; Hughes, 2017; Martek et al., 2019) because of the mistaken assumption that the domestic end-user is 'onboard' with the zero-emissions agenda (van der Heijden, 2014, 2018). To answer that home owners are 
not buying sustainable homes because there are none to buy, generates a cycle of recrimination (refer to Figure 2).

\section{$<<$ Insert Figure 2 Here $>>$}

Figure 2. The 'Cycle of Blame,' describing why sustainable buildings are not being built (source: adapted from Meyers et al. (2008))

Belatedly, government has diagnosed the sources of resistance to sustainability adoption, noted in research as 'drivers and barriers,' and consequently devised remedial solutions, typically identified as push and pull (carrot and stick) measures available to them (Olubunmi et al., 2016; van der Heijden, $\underline{2013}$ ). These were the policy platforms of regulations, financial interventions and communication (behavioral change mechanisms) - refer to Figure 3.

\section{$<$ Insert Figure 3 Here $>>$}

Figure 3. The traditional sustainability paradigm (source: authors)

Indeed, the Achilles heel of the drive to imbed sustainability practices within the urban fabric is that 'green values' remain an elitist ideal and do not resonate with the broader community (Onuoha et al., 2018; van der Heijden, 2018). Ordinary citizens don't understand them, don't see that they deliver worthwhile benefits, or just don't care - other priorities being far more important (van der Heijden, 2013, $\underline{2014}, 2018)$. Thus, the paradigm should shift from 'government seeks to attract industry engagement into the sustainability project,' to 'residential end-user motivations to shift to sustainable housing must be triggered with appropriate catalysts.'

The motivators driving ordinary citizens to adopt sustainable housing break down into four thematic groups: 1) economics - the possibility that a green building may extract higher rents or exact a higher resale price; 2) fashion - akin to the virtue signaling of corporations, in which wealthier individuals flaunt the trend through indulgent real-estate; 3) altruism - where people take comfort in 'doing good;' and 4) quality of life - where buildings offer a better living experience, rather than sustainability per se (ASBEC, 
2017; Centre for Liveability Real Estate, 2018; Olubunmi et al., 2016; van der Heijden, 2013; Xia et al., $\underline{2018})$.

Though there is still no consensus on the degree of influence of various incentives for green buildings, monetary imperative remains most influential (Chileshe et al., 2018; Olubunmi et al., 2016; $\underline{\text { van der }}$ Heijden, 2013). The rather ingenious recommendation that emerges from this observation is that if economic incentives are a key to engineering sustainability adoption, then this should also be applied to housing. Rather than relying on the carbon tax or emissions trading, a financial incentive should be introduced into the mortgage market (van der Heijden, 2013). Since housing affordability remains the main impediment to buying homes, with cost considerations the driving force in residential purchases (Tapsuwan et al., 2018), government should make sustainable housing more affordable than traditional housing. This means mortgage relief, rebate concessions or tax breaks, similar to incentives offered to first-home-buyers (refer to Figure 4).

\section{$<<$ Insert Figure 4 Here $>>$}

Figure 4. An alternate sustainability paradigm (source: authors)

Currently, governments across various states offer a 'first-home buyers' scheme. Shaping policy around a discounted mortgage rate initiative for purchases of sustainability compliant properties can be an effective measure to engage residential sector end-users. The modeling for this rebate could be based on current emissions trading schemes (ETSs) or carbon tax (CT). There are 17 ETSs operating in 34 countries around the world, while 17 countries collect a carbon tax. ETSs cover 4,280 $\mathrm{MtCO}_{2}$ emissions (71\%) while CTs cover 1,778 $\mathrm{MtCO}_{2}$ emissions (29\%), annually. Overall, national efforts to price carbon into the economy appear to be generating desired positive effects, including changes of behavior in commercial practices. Here then lies a clue, but two things stand out.

Firstly, while the built environment remains by far the biggest contributor to greenhouse gas emissions, this is not a sector specifically targeted in ETS or CT schemes. Secondly, these schemes place emphasis 
on the initial stages of the manufacturing value chain where component elements are disaggregated, and calculations are easier to make. If, on the other, building rating systems could be further refined to generate a reliable 'emissions over life-cycle' calculation, then buildings able to demonstrate performance levels above a set mandated threshold, should be made eligible for the equivalent carbon rebate. An initiative of this sort would offer a clear financial incentive to home-buyers. And with their piqued interest, the whole residential construction market could be expected to realign to genuinely focus on sustainability, and work towards government's Paris Accord promises.

\section{REORGANIZING THE BUILDING SECTOR}

Policy making for promoting sustainability transition within the Australian building industry has been based on the hypothesis that various incentives that stimulate demand for green buildings will work bottom up to shake the market (its suppliers, builders and developers) into generating innovations that deliver supply (van der Heijden, 2018). The examples of showcase green iconic buildings have trickled down to find greater embrace amongst a wide base of commercial buildings. The presumption is that this trickle-down effect will continue to the residential sector and see domestic home buyers and renters adopt greener buildings. Drawing upon a comprehensive review of sustainability transition literature in Australia, and using an end-user oriented lens, the inadequacy of this assumption - and wider political expectation - is exposed. At a minimum, the uptake of green properties within the Australian residential sector is inadequate to achieve Australia's international commitments and national targets for zero carbon emissions. The main weakness lies in the insufficiency of the current array of motivators to generate the necessary critical mass within the residential home market to produce sufficient momentum for a 'green transition.' Certainly, a transition is occurring and can be expected to gain significant positive outcomes, but it would appear not in the time frame promised by government.

It must be stated that this finding is not a value judgment of the aims, methods, or capabilities of the parties involved. Setting an extreme target, as has been done with regards to Australia's carbon emissions 
ambitions, is itself a mechanism for achieving accelerated results, even when achieving those results fully was never a viable possibility.

A summary of what the current peer-reviewed literature reveals, as major themes to be considered in reorganizing the building sector, is restated here:

- Buildings are a major source of environmental damage and green-house gas emissions, of which residential buildings constitute the greater portion.

- Australia has set itself aggressive carbon emission targets, with a commitment to net zero emissions by 2050 .

- Current performance in Australia indicates these targets will not be met.

- Green rating tools regimes have arisen in response to global emissions concerns, are the primary mechanism by which 'greenness' of building is assessed, and in Australia the regime is mostly represented by locally developed instruments: Green Star and NABERS.

- Despite the positive contributions and on-going evolution of the Australian rating instruments, insufficiencies have been noted by a number of researchers.

- Notable among the deficiencies is the quality of environment performance discrepancy of green buildings as reported by building procurers and their occupants.

- Another notable barrier to 'greening' buildings is the enduring (though diminishing) negative cost benefit payoff.

- The extra cost of going green, the limited availability of affordable green housing alternatives, and the limited understanding and/or acceptance of the benefits of going green, present as an impediment to adoption by the residential market.

- Apart from affordability, in choosing homes, residential home-owners/renters prioritize, access to jobs, transport, schools, facilities, low crime etc. over narrowly defined 'green' concerns. This creates a dislocation between strictly zero-carbon green objectives, and the economic, social and cultural objectives also encompassed by sustainability, more broadly defined. 
- Governmental incentives have been three-pronged: regulatory, financial and educational. While achieving some good results, the inertia has been significant.

- A cycle of blame exists between building occupiers, constructors, developers, investors, and indeed government, as to who should take the lead in unblocking further impediments.

- It would appear that any further progress in incentivizing the residential market to achieve greater 'green' uptake will involve greater financial incentives: support for industry innovation, as well as rebates, preferred loans, tax concessions, or the like, for home-buyers.

\section{CONCLUSION}

As a point of departure from previous studies conducted, this study gives priority to the residential market in Australia that has remained under-represented in the literature even though it represents a major part of Australia's building industry. The key contribution of this study is providing an updated picture of the landscape of research on end-users of the residential market, their role, interests, and impacts. Findings provide insight into potential avenues for enhancing end-users' demand, in order to drive and put pressure on the supply side of the housing market to provide more sustainable housing. The study suggests that through competition generated by demand-side invigoration, government can expect better results in securing urban sustainability, and into the untouched domain of residential sector. The study also stands out among similar works on the topic, given that it extends the end-users debate beyond the importance and influence argument; this study moves to the policy-making domain through formulating guidelines and outlining a proposal for applying the green building incentives for first-home-buyers, as an innovative consideration that directly links end-user property purchase priorities with government's sustainability objectives. Moreover, it is economically rational because it would neutralize the incentive to transfer present costs of emissions to future generations.

Despite the contributions above, and prior to drawing any conclusion, it is pertinent to acknowledge several limitations. First, the chosen research approach, in focusing on the Australian context, limits the transferability of the findings to other contexts. Consequently, research findings are to be treated with 
moderatum generalisations (see Payne and Williams (2005)). Second, due to the conceptual nature of the study, suggestions and recommendations should be validated and tested in future studies and using empirical data.

Finally, major questions remain unanswered: how would this work, what level of rebate - for whom, for what and is it possible for government to work with big banks and legislate a mortgage rebate. There are precedents that offer instructive models that might be followed but these questions call for a further finegrained investigation that would be the subject of a follow-up study to this review.

\section{Acknowledgement}

This work was funded by the Integral Design Futures (IDF) funding scheme's 2018 program:

Towards end-user engagement in Australian Green Star revolution (School of Architecture and

Built Environment, Deakin University).

\section{REFERENCES}

ABS, 2018. Australian Population Data. http://www.abs.gov.au/ausstats/abs@.nsf/0/1647509ef7e25faaca2568a900154b63?OpenDocument. (Accessed 10 August, 2018.

Alberg Mosgaard, M., Kerndrup, S., Riisgaard, H., 2016. Stakeholder constellations in energy renovation of a Danish Hotel. Journal of Cleaner Production 135, 836-846.

Albino, V., Berardi, U., 2012. Green Buildings and Organizational Changes in Italian Case Studies. Business Strategy and the Environment 21(6), 387-400.

Altmann, E., 2014. Apartments, Co-ownership and Sustainability: Implementation Barriers for Retrofitting the Built Environment. Journal of Environmental Policy \& Planning 16(4), 437-457.

Ambrose, A.R., 2015. Improving energy efficiency in private rented housing: Why don't landlords act? Indoor and Built Environment 24(7), 913-924.

Ang, S., Wilkinson, J., 2008. Is the social agenda driving sustainable property development in Melbourney, Australia? Sustainable Property Development 26(5), 331-343.

Arashpour, M., Wakefield, R., Abbasi, B., Arashpour, M., Hosseini, R., 2018. Optimal process integration architectures in off-site construction: Theorizing the use of multi-skilled resources. Architectural Engineering and Design Management 14(1-2), 46-59. 
Armitage, L., Murugan, A., Kato, H., 2011. Green offices in Australia: a user perception survey. Journal of Corporate Real Estate 13(3), 169-180.

ASBEC, 2016. A national framework for residential ratings: Discussion paper. http://www.asbec.asn.au/research-items/residential-ratings/. (Accessed 27 April 2018).

ASBEC, 2017. ASBEC submission on review of Australia's climate change policies. https://www.asbec.asn.au/wordpress/wp-content/uploads/2017/04/170427-ASBEC-Submission-ClimateChange-Policy-Review.pdf. (Accessed 13 September 2018).

Australian Government, 2018. Australia's 2030 climate change target.

http://www.environment.gov.au/climate-change/publications/factsheet-australias-2030-climate-changetarget [Accessed 10 August 2018].

Becker, J., 2004. Making sustainable development evaluations work. Sustainable Development 12(4), 200-211.

Berardi, U., 2013. Stakeholders' influence on the adoption of energy-saving technologies in Italian homes. Energy Policy 60, 520-530.

Berardi, U., 2015. Sustainability assessments of buildings, communities and cities, in: Klemes, J. (Ed.) Assessing and measuring environmental impact and sustainability. Elsevier, UK, pp. 497-545.

Berry, S., Marker, T., 2015. Residential energy efficiency standards in Australia: where to next? Energy Efficiency 8(5), 963-974.

Best, R., Purdey, B., 2012. Assessing occupant comfort in an iconic sustainable education building. Journal of Construction Economics and Building 12(3), 55-65.

Beyond Zero Emissions, 2018. Australian Local Government Climate Review. Beyond Zero Emissions, ICLEI - Local Governments for Sustainability (ICLEI Oceania) and Ironbark Sustainability, Melbourne, Australia.

Bond University, 2011. Sustainable Development building. https://bond.edu.au/about-bond/facilitiesservices/teaching-facilities/sustainable-development-building. (Accessed 13 September 2018).

Bondareva, E., 2008. Green star - LEED's Australian Cousin. Journal of Green Building 2(3), 32-40.

BREEAM, 2018. What is BREEAM? http://www.breeam.com/. (Accessed 11 September 2018).

Candy, S., Larsen, K., Twomey, P., McGrail, S., Ryan, C., 2017. Pathways 2040. Results from Visions and Pathways 2040: Scenarios and Pathways to Low Carbon Living. CRC for Low Carbon Living, Melbourne, Australia.

CASBEE, 2018. CASBEE Homepage. http://www.ibec.or.jp/CASBEE/english/. (Accessed 2018, 02, 12.

Centre for Liveability Real Estate, 2018. The New Value Proposition for Australian Homes. https://liveability.com.au/the-new-value-proposition/. (Accessed 11 September 2018).

Chan, A.P.C., Darko, A., Ameyaw, E.E., 2017. Strategies for promoting green building technologies adoption in the construction industry—An international study. Sustainability 9(6), 969. 
Chileshe, N., Rameezdeen, R., Hosseini, M.R., Martek, I., Li, H.X., Panjehbashi-Aghdam, P., 2018. Factors driving the implementation of reverse logistics: A quantified model for the construction industry. Waste Management 79, 48-57.

City of Melbourne, 2018. Zero Net Emissions Strategy. https://www.melbourne.vic.gov.au/aboutcouncil/vision-goals/eco-city/Pages/zero-net-emissions-strategy.aspx. (Accessed 10 September 2018).

ClimateWorks, 2016. Low carbon, high performance: How buildings can make a major contribution to Australia's emissions and productivity goals. Australian Sustainable Built Environment Council, Sydney, Australia.

ClimateWorks, 2018. Expert report: Improve home energy standards or risk bigger bills, more emissions. https://climateworks.com.au/story/media-release/expert-report-improve-home-energy-standards-or-riskbigger-bills-more-emissions. (Accessed 27 April 2018).

Crawford, R., Bartak, E., Stephan, A., Jensen, C., 2015. Does current policy on building energy efficiency reduce a building's life-cycle energy demand?, Living and Learning: Research for a Better Built Environment, 49th International Conference of the Architectural Science Association. Melbourne, pp. $332-341$.

CRC, 2018. CRCLCL Tools Catalogue. http://www.lowcarbonlivingcrc.com.au/resources/crcpublications/fact-sheet/crclcl-tools-catalogue. (Accessed 13 September 2018).

Darko, A., Chan, A.P.C., 2016a. Critical analysis of green building research trend in construction journals. Habitat International 57, 53-63.

Darko, A., Chan, A.P.C., 2016b. Review of Barriers to Green Building Adoption. Sustainable Development 25(3), 167-179.

DECC NSW, 2014. Sustainable Property Guide.

https://www.environment.nsw.gov.au/publications/business/090129-sustainable-property-guide.htm. (Accessed 14 September 2018).

Ding, G., 2008. Sustainable construction - The role of environmental assessment tools. Journal of Environmental Management 86, 451-464.

Ding, G., 2010. Sustainability assessment of residential development - An Australian experience. The International Journal of Construction Management 10(2), 19-32.

Ding, G., 2013. Strategies for sustainable housing development - The challenges from renewable energy. International Journal for Housing Science 37(4), 239-248.

Dixit, M.K., Culp, C.H., Fernandez, -.S., J.L., 2013. System boundary for embodied energy in buildings: A conceptual model for definition. Sustainable Energy Review 21, 153-164.

Doan, D.T., Ghaffarianhosseini, A., Naismith, N., Zhang, T., Ghaffarianhosseini, A., 2017. A critical compariosn of green building rating systems. Building and Environment 123, 243-260.

Foong, D., Mitchell, P., Wagstaff, N., Duncan, E., McManus, P., 2017. Transitioning to a more sustainable residential built environment in Sydney? Geo: Geography and Environment 4(1), e00033-n/a. 
Freig, A., Wallbaum, H., Janser, M., Windlinger, L., 2013. Impact of sustainable office buildings on occupant's comfort and productivity. Journal of Corporate Real Estate 15(1), 7-34.

Gabriel, M., Watson, P., 2012. Supporting Sustainable Home Improvement in the Private Rental Sector: The View of Investors. Urban Policy and Research 30(3), 309-325.

Gabriel, M., Watson, P., Ong, R., Wood, G., Wulff, M., 2010. The environmental sustainability of Australia's private rental housing stock, AHURI Final Report No. 159. Australian Housing and Urban Research Institute, Melbourne.

Gan, X., Zuo, J., Ye, K., Skitmore, M., Xiong, B., 2015. Why sustainable construction? Why not? The owner's perspective. Habitat International 47, 61-68.

GBCA, 2018. Green Star. https://new.gbca.org.au/. (Accessed 3 March 2018).

Ghaffarianhosseini, A., Berardi, U., Alwaer, H., Chang, S., Halawa, E., Ghaffarianhosseini, A., Croome, D., 2016. What is an intelligent building? Analysis of recent interpretations from an international perspective. Architectural Science Review 59(5), 338-357.

Gil, J., Durante, J., 2011. Tools for evaluating the sustainability of urban design: A review . Proceedings of the Institute of Civil Engineers, Urban Design and Planning. Ice Publishing.

Gonzalez, C., 2007. Whay a tree-lined nature strip can add 30 per cent to your property value, The Sydney Morning Herald, 9 March, 2007 ed.

Gorgolewski, C.B.M., 2014. Assessing occupant satisfaction and energy behaviours in Toronto's LEED Gold high-rise residential buildings. International Journal of Construction Management 4(4), 492-505.

Gou, Z., Prasad, D., Lau, S., 2013. Are green buildings more satisfactory and comfortable? Habitat International 39, 156-161.

Gou, Z., Xie, X., 2017. Evolving green building: triple bottom line or regenerative design? Journal of Cleaner Production 153, 600-607.

Hakkinen, T., Belloni, K., 2011. Barriers and drivers for sustainable building. Building Research \& Information 39(3), 239-255.

Hall, S., 2014. Development and initial trial of a tool to enable improved energy and human performance in existing commercial buildings. Renewable Energy 67, 109-118.

Harrington, P., 2017. Leading the way: Low carbon policies and measures in Australia's capital cities. Cooperative Research Centre for Low Carbon Living, Sydney.

Hartig, T., Bringslimark, T., Patil, G., 2007. Restorative environmental design, in: Kellert, S., Heerwage, J., Mador, M. (Eds.), Bringing Buildings to Life: The Theory and Practice of Biophilic Building Design. Wiley, New York.

Hatvani-Kovacs, G., Belusko, M., Pockett, J., Boland, J., 2018. Heat stress-resistant building design in the Australian context. Energy and Buildings 158, 290-299.

He, Y., Kvan, T., Liu, M., Li, B., 2018. How green building rating systems affect designing green. Building and Environment 133, 19-31. 
Hirning, M.B., Isoardi, G.L., Coyne, S., Hansen, V.R., Cowling, I., 2013. Post-occupancy evaluations relating to discomfort glare: A study of green buildings in Brisbane. Building and Environment 59, 349357.

Hoffman, A.J., Hen, R., 2008. Overcoming the social and psychological barriers to green building. Organization \& Environment 21, 390-419.

Hoornweg, D., Sugar, L., Trejos Gomez, C.L., 2011. Cities and greenhouse gas emissions: moving forward. Environment and Urbanization 23(1), 207-227.

Hosseini, M.R., Banihashemi, S., Rameezdeen, R., Golizadeh, H., Arashpour, M., Ma, L., 2017. Sustainability by Information and Communication Technology: A paradigm shift for construction projects in Iran. Journal of Cleaner Production 168, 1-13.

Hosseini, M.R., Martek, I., Zavadskas, E.K., Aibinu, A.A., Arashpour, M., Chileshe, N., 2018. Critical evaluation of off-site construction research: A Scientometric analysis. Automation in Construction 87, 235-247.

Hughes, L., 2017. In the absence of national leadership, cities are driving climate policy. http://theconversation.com/in-the-absence-of-national-leadership-cities-are-driving-climate-policy- 81108 . (Accessed 7 September 2018).

Iyer-Raniga, U., Moore, T., Wasiluk, K., 2014. Residential building sustainability rating tools in Australia. Environment Design Guide(80), 1-14.

Jailani, J., Reed, R., James, K., 2015. Examining the perception of tenants in sustainable office buildings. Property Management 33(4), 386-404.

Kato, H., Too, L., Rask, A., 2009. Occupier perceptions of green workplace environment: The Australian experience. Journal of Corporate Real Estate 11(3), 183-195.

Kats, G., 2003. The costs and benefits of green: A report to California's sustainable building task force. Capital E Analytics, Washington DC.

Lau, Z., 2013. Post-occupancy evaluation of the thermal environment in a green building. Facilities 31(7/8), 357-371.

Leaman, A., Bordass, B., 2001. Assessing building performance in use. Building Research and Information 29, 129-143.

Leaman, A., Bordass, B., 2007. Are users more tolerant of green buildings? Building Research and Information 35(6), 662-673.

LEED, 2018. LEED Homepage. https://new.usgbc.org/leed. (Accessed 2018, 02, 12.

Li, H., Patel, D., Al-Hussein, M., Yu, H., Gul, M., 2018. Stakeholder studies and the social networks of NetZero energy homes. Sustainable Cities and Society 38, 9-17.

Li, X., Strezov, V., Amati, M., 2013. A qualitative study of motivation and influences for academic green building developments in Australian universities. Journal of Green Building 8(3), 166-183. 
Lin, A.C., 1998. Bridging Positivist and Interpretivist Approaches to Qualitative Methods. Policy Studies Journal 26(1), 162-180.

Love, P.E.D., Niedzweicki, M., Bullen, P.A., Edwards, D.J., 2012. Achieving the Green Building Council of Australia's World Leadership Rating in an Office Building in Perth. Journal of Construction Engineering and Management 138(5), 652-660.

Luther, M., 2017. Developing an 'as performing' building assessment. Journal of Green Building 4(3), $113-120$.

Mallawaarachchi, H., DeSilva, L., Rameezdeen, R., 2017. Modelling the relationship between green built environment and occupants' productivity. Facilities 35(3/4), 170-187.

Mao, X., Lu, H., Li, Q., 2009. A comparison study of mainstream sustainable/green building rating tools in the world. Management and Service Science, 1-5.

Mapes, J., Wolch, J., 2011. 'Living green': The promise and pitfalls of new sustainable communities. Journal of Urban Design 16(1), 105-126.

Marjaba, G.E., Chidiac, S.E., 2016. Sustainability and resiliency metrics for buildings - Critical review. Building and Environment, 116-125.

Martek, I., Hosseini, M.R., 2018. Greenwashing the property market: why 'green star' ratings don't guarantee more sustainable buildings. http://theconversation.com/greenwashing-the-property-marketwhy-green-star-ratings-dont-guarantee-more-sustainable-buildings-91655. (Accessed 12 September 2018).

Martek, I., Hosseini, M.R., Shrestha, A., Edwards, D.J., Durdyev, S., 2019. Barriers inhibiting the transition to sustainability within the Australian construction industry: An investigation of technical and social interactions. Journal of Cleaner Production 211, 281-292.

Martek, I., Hosseini, M.R., Shrestha, A., Zavadskas, E.K., Seaton, S., 2018. The sustainability narrative in contemporary architecture: Falling short of building a sustainable future. Sustainability 10(981).

Mattoni, B., Guattari, C., Evangelisti, L., Bisegna, F., Gori, P., Asdrubali, F., 2018. Critical review and methodological approach to evaluate the differences among international green building rating tools. Renewable and Sustainable Energy Reviews 82, 950-960.

Mcguirk, P., Dowling, R., Brennan, C., Bulkeley, H., 2015. Urban Carbon Governance Experiments: The Role of Australian Local Governments. Geographical Research 53(1), 39-52.

Meyers, G., Reed, R., Robinson, J., 2008. Sustainable property - The future of the New Zealand market. Pacific Rim Property Research Journal 14(3), 298-321.

Mulvaney, D., 2013. Opening the black box of solar energy technologies: exploring tensions between innovation and environmental justice. Science as Culture 22(2), 230-237.

Ness, D., Xing, K., 2017. Toward a resource efficient built environment: A literature and conceptual model. Journal of Industrial Ecology 21(3), 572-592. 
Olanipekun, A., Xia, B., Hon, C., Hu, Y., 2017. Project owners' motivation for delivering green building projects. Journal of Construction Engineering and Management 143(9).

Olubunmi, O.A., Xia, P.B., Skitmore, M., 2016. Green building incentives: A review. Renewable and Sustainable Energy Reviews 59, 1611-1621.

Onuoha, I.J., Aliagha, G.U., Rahman, M.S.A., 2018. Modelling the effects of green building incentives and green building skills on supply factors affecting green commercial property investment. Renewable and Sustainable Energy Reviews 90, 814-823.

Ottosson, J., Grahn, P., 2005. A comparison of leisure time spent in garden with leisure time spent indoors. Landscape Research 30, 23-55.

Papajohn, D., Brinker, C., Asmar, M.E., 2017. MARS: Metaframework for Assessing Ratings of Sustainability for Buildings and Infrastructure. Journal of Management in Engineering 33(1), 04016026.

Paul, W., Taylor, P., 2008. A comparison of occupant comfort and satisfaction between a green building and a conventional building. Building and Environment 43, 1858-1870.

Payne, G., Williams, M., 2005. Generalization in Qualitative Research. Sociology 39(2), 295-314.

Productivity Commission, 2013. Barriers to Effective Climate Change Adaptation.

https://www.pc.gov.au/inquiries/completed/climate-change-adaptation. (Accessed 13 September 2018).

Property Council of Australia, 2001. Sustainable development. A roadmap for the commercial property industry. PCA, Sydney.

Rameezdeen, R., Zuo, J., Ochoa Paniagua, J., Wood, A., Do, P., 2019. Ensuring environmental performance in green leases: the role of facilities managers. Facilities $0(0)$, null.

Ravindu, S., Rameezdeen, R., Zuo, J., Zhou, Z., 2015. Indoor environment quality of green buildings: Case study of a LEED platinum certified factory in a warm humbid tropical climate. Building and Environment 84, 105-113.

Ruggiero, S., Onkila, T., Kuittinen, V., 2014. Realizing the social acceptance of community renewable energy: A process-outcome analysis of stakeholder influence. Energy Research \& Social Science 4, 5363.

Saman, W.Y., 2013. Towards zero energy homes down under. Renewable energy 49, 211-215.

Sander, L., 2018. A new study should be the final nail for open-plan offices. http://theconversation.com/anew-study-should-be-the-final-nail-for-open-plan-offices-99756. (Accessed 13 September 2018).

Sandy, B., 2011. Barriers and drivers to green buildings in Australia and New Zealand. Journal of Property Investment \& Finance 29(4/5), 494-509.

Shad, R., Khorrami, M., Ghaemi, M., 2017. Developing an Iranian green building assessment tool using decision making methods and geographical information system: Case study in Mashhad city. Renewable and Sustainable Energy Reviews 67, 324-340.

Shafaghat, A., Kreyvanfar, A., Ferwati, M., Alizadeh, T., 2015. Enhancing staff satisfaction with comfort toward productivity by sustainable open plan office design. Sustainable Cities and Society 19, 151-164. 
Shen, L., Tam, V., Tam, L., Ji, Y., 2010. Project feasibility study: The key to successful implementation of sustainable and socially responsible construction mangement practice. Journal of Cleaner Production $18,254-259$.

Shi, Q., Yan, Y., Zuo, J., Yu, T., 2016. Objective conflicts in green building projects: A critical analysis Building and Environment 96, 101-117.

Siew, R., 2015. Alternative framework for assessing sustainable building funds: Green building fund. Building Research \& Information 43(3), 160-169.

Siva, V., Hoppe, T., Jain, M., 2017. Green Buildings in Singapore; Analyzing a Frontrunner's Sectoral Innovation System. Sustainability 9(6), 919.

Smoleniec, L., McManus, P., Duncan, E., 2017. Understanding the dynamics of sustainability transitions: the Home Insulation Program. Australian Geographer 48(4), 497-517.

Sulivan, L., Ridin, Y., Buchanan, C., 2014. Neighbourhood sustainability frameworks - A literature review, Working Paper Series. Centre for Urban Sustainability \& Resilience, University College, London, UK.

Sutton, M., 2018. Modern homes trapping heat 'like a plastic bag'. http://www.abc.net.au/news/2018-0104/australian-houses-losing-in-heat-management-design/9287188. (Accessed 10 August, 2018.

Tam, V., Zeng, S.X., 2013. Sustainable performance indicators for Australian residential buildings. Journal of Legal Affairs and Dispute Resolution in Engineering and Construction 5(4), 168-179.

Tam, V.W.Y., Karimipour, H., Le, K.N., Wang, J., 2018. Green neighbourhood: Review on the international assessment systems. Renewable and Sustainable Energy Reviews 82, 689-699.

Tapsuwan, S., Mathot, C., Walker, I., Barnett, G., 2018. Preferences for sustainable, liveable and resilient neighbourhoods and homes: A case of Canberra, Australia. Sustainable Cities and Society 37, 133-145.

Taylor, A.F., Kuo, F.E., Sullivan, W.C., 2002. Views of nature and self-discipline. Journal of Environmental Psychology 22, 49-63.

Thomas, L., 2010. Calculating the green in gree: What is an urban tree worth?, Science Findings. Pacific Northwest Research Station.

Udawatta, N., Zuo, J., Chiveralls, K., Zillante, G., 2015. Attitudinal and behavioural approaches to improving waste management on construction projects in Australia. International Journal of Construction Management 15, 137-147.

van der Heijden, J., 2013. Voluntary Environmental Governance Arrangements in the Australian Building Sector. Australian Journal of Political Science 48(3), 349-365.

van der Heijden, J., 2014. Green building revolution? Only in high-end new CBD offices. http://theconversation.com/green-building-revolution-only-in-high-end-new-cbd-offices-24535. (Accessed 22 February 2018).

van der Heijden, J., 2015. On the potential of voluntary environmental programmes for the built environment: A critical analysis of LEED. Journal of Housing and Built Environment November. 
Van der Heijden, J., 2016. The new governance for low-carbon buildings: mapping, exploring, interrogating. Building Research \& Information 44(5-6), 575-584.

van der Heijden, J., 2018. From leaders to majority: a frontrunner paradox in built-environment climate governance experimentation. Journal of Environmental Planning and Management, 1-19.

Vierra, S., 2016. Green building standards and certification systems.

https://www.wbdg.org/resources/green-building-standards-and-certification-systems. (Accessed 11 September 2018).

Warren-Myers, G., 2017. New homebuyers and the challenges of navigating sustainability and energy efficiency with Australian volume builders. Energy Procedia 134, 214-223.

Warren-Myers, G., Judge, M., Paladino, A., 2018. Sustainability ratings in residential development: a worthwhile endeavour? International Journal of Building Pathology and Adaptation 36(4), 353-372.

Wells, N.M., 2000. At home with nature. Environment and Behavior 32, 775-795.

Wilkinson, S., 2014. Report for Royal Institution of Chartered Surveyors.

Wilson, J.L., Tagaza, E., 2006. Green buildings in Australia: drivers and barriers. Australian Journal of Structural Engineering 7(1), 57-63.

Wu, G., Zuo, J., Zhao, X., 2017. Incentive model based on cooperative relationship in sustainable construction projects. Sustainability 9(1191).

Xia, B., Olanipekun, A., Chen, Q., Xie, L., Liu, Y., 2018. Conceptualising the state of the art of corporate social responsibility (CSR) in the construction industry and its nexus to sustainable development. Journal of Cleaner Production 195, 340-353.

Xia, B., Zuo, J., Skitmore, M., Pullen, S., Chen, Q., 2013. Green Star points obtained by Australian building projects. Journal of Architectural Engineering 19(4), 302-308.

Zalejska-Jonsson, A., 2014. Parameters contributing to occupants satisfaction. Facilities 32(7/8), 411-437.

Zhang, L., El-Gohary, N.M., 2016. Discovering Stakeholder Values for Axiology-Based Value Analysis of Building Projects. Journal of Construction Engineering and Management 142(4), 04015095.

Zuo, J., Xia, B., Barker, J., Skitmore, M., 2014. Green buildings for greying people: A case study of a retirement village in Australia. Facilities 32(7/8), 365-381.

Zuo, J., Xia, B., Chen, Q., Pullen, S., Skitmore, M., 2018. Green building rating for office buildings Lessons learned. Journal of Green Building 11(2), 131-146.

Zuo, J., Zhao, Z.Y., 2014. Green building research - Current status and future agenda: A review. Renewable and Sustainable Energy Reviews 30, 271-281. 


\begin{tabular}{|c|c|c|}
\hline \multicolumn{3}{|c|}{ Rating sustainability } \\
\hline & $\begin{array}{c}\text { LEED } \\
1998\end{array}$ & \multirow{2}{*}{$\begin{array}{l}\text { BREEAM } \\
1990\end{array}$} \\
\hline & $\begin{array}{l}\text { CASBEE } \\
2002\end{array}$ & \\
\hline \multicolumn{3}{|c|}{ Australia } \\
\hline \multirow{2}{*}{\multicolumn{3}{|c|}{$\begin{array}{l}\text { Minimal mandatory } \\
\text { requirements }\end{array}$}} \\
\hline & & \\
\hline National Construction Code (NCC) & \multicolumn{2}{|l|}{ Green Star } \\
\hline $\begin{array}{l}\text { Nationwide House Energy Rating Scheme } \\
\text { (NatHERS) }\end{array}$ & \multicolumn{2}{|c|}{$\begin{array}{l}\text { National Australian Built Environment Rating System } \\
\text { (NABERS) }\end{array}$} \\
\hline \multicolumn{3}{|c|}{ Emerging trends } \\
\hline \multicolumn{3}{|c|}{ Value chain assessment } \\
\hline \multicolumn{3}{|c|}{ Whole of lifecycle } \\
\hline \multicolumn{3}{|c|}{ Intelligent buildings } \\
\hline \multicolumn{3}{|c|}{ Optimization modeling } \\
\hline \multicolumn{3}{|c|}{ Resource efficiency } \\
\hline \multicolumn{3}{|c|}{ Cooperative incentivization } \\
\hline \multicolumn{3}{|c|}{ Zero energy } \\
\hline
\end{tabular}




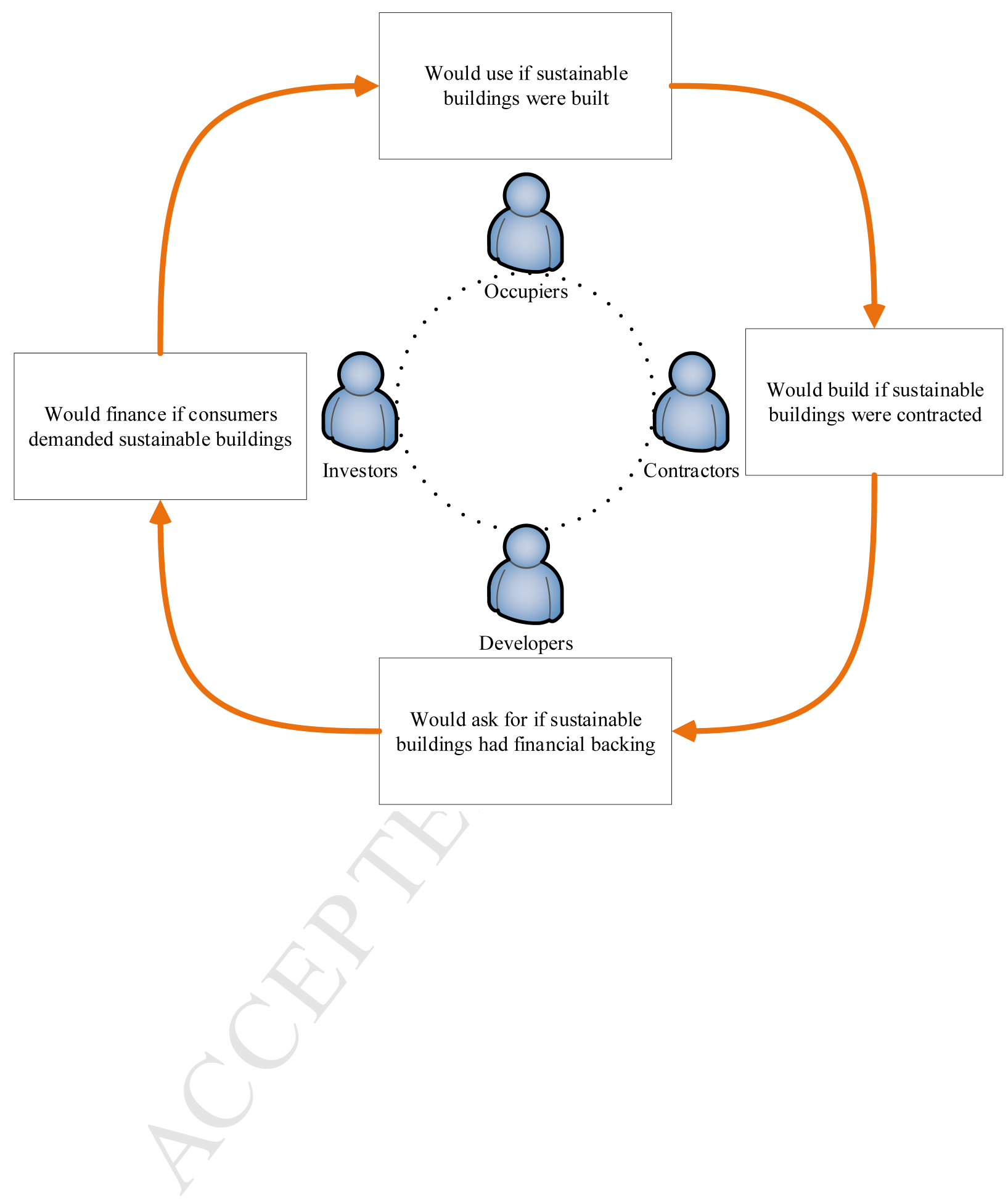




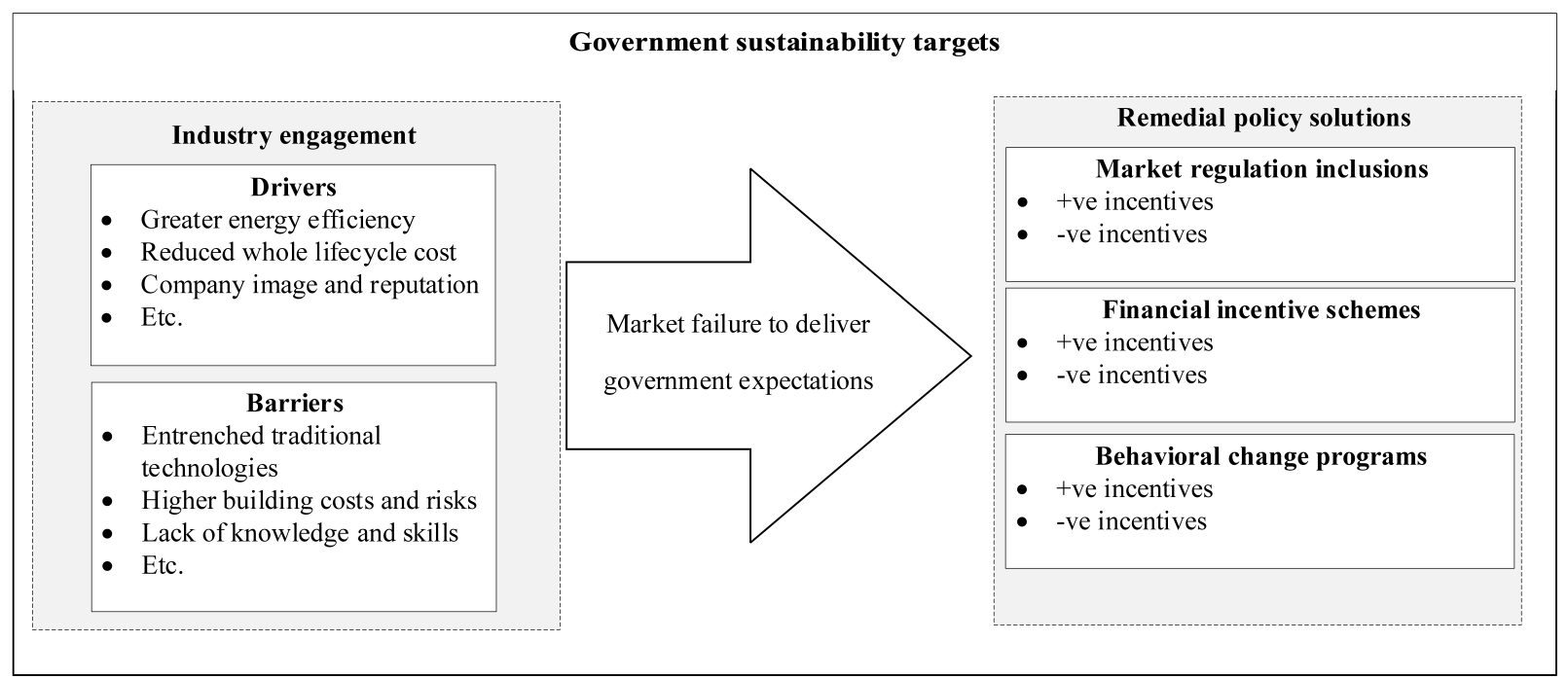




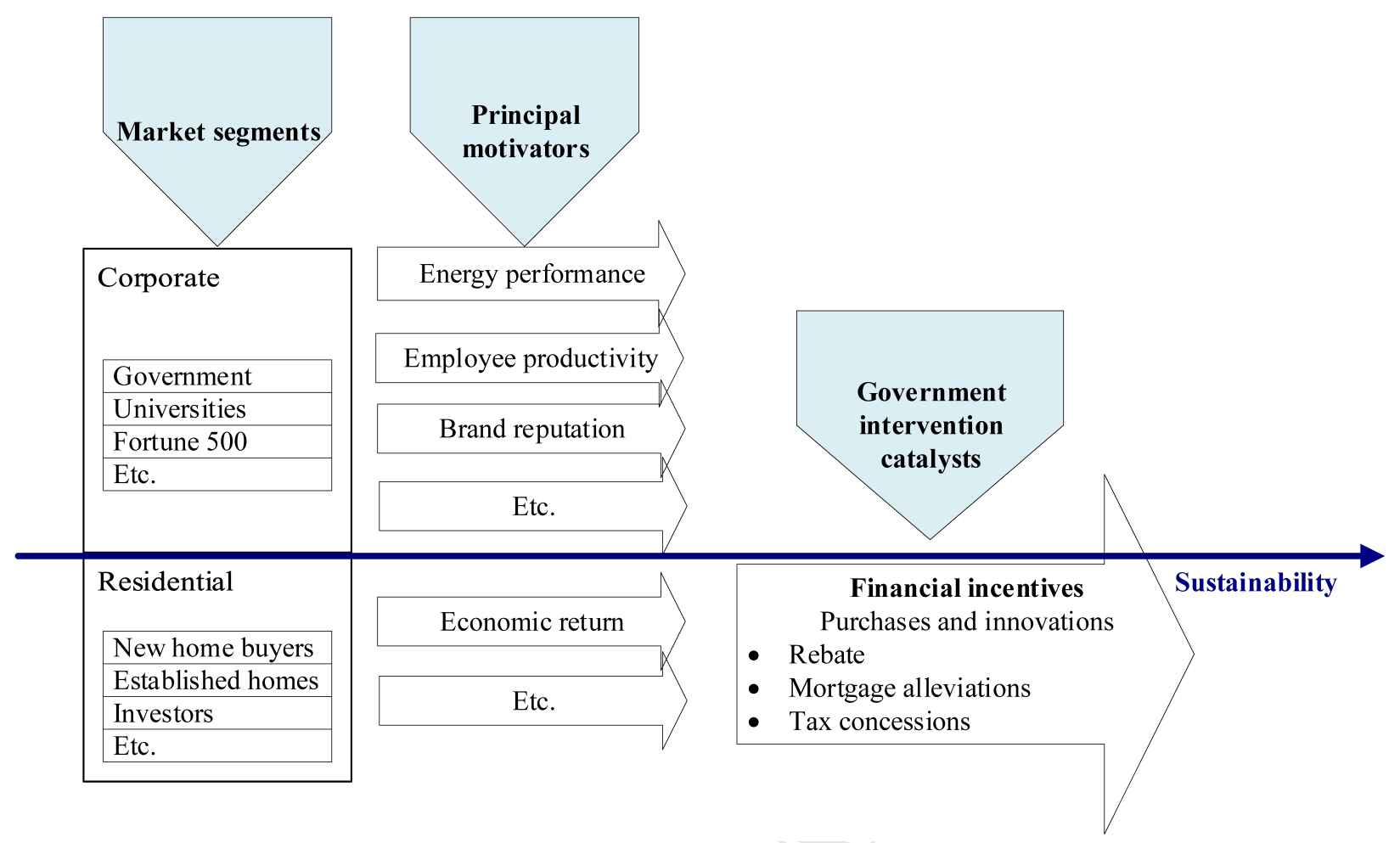




\section{Highlights}

- Attempts to transform Australia's urban environment into a sufficiently sustainable one has failed in generating desirable outcomes.

- A systematic review of 103 journal articles is conducted on the topic of end-users and sustainability transition.

- Residential end-users do not purchase green homes and without their 'buy-in,' sustainability transition across Australia will continue to fail.

- Financial incentives for the purchase of low-carbon buildings must be introduced into the residential real-estate market.

- The modeling for the rebate is discussed in terms of emissions trading schemes or carbon tax. 